\title{
A study investigating the association of dermatological and infusion reactions to infliximab and infliximab trough levels
}

\author{
Vivian Wai-Mei Huang MSc MD FRCPC ${ }^{1}$, Neil Dhami BSc ${ }^{1}$, Darryl Fedorak BSc ${ }^{1}$, Connie Prosser PhD², \\ Carol Shalapay $\mathrm{MLT}^{2}$, Karen Ivy Kroeker MSc MD FRCPC ${ }^{1}$, Brendan Phillip Halloran MD FRCPC ${ }^{1}$, \\ Levinus Albert Dieleman MD PhD ${ }^{1}$, Richard Neil Fedorak MD FRCPC ${ }^{1}$
}

\begin{abstract}
VWM Huang, N Dhami, D Fedorak, et al. A study investigating the association of dermatological and infusion reactions to infliximab and infliximab trough levels. Can J Gastroenterol Hepatol 2015;29(1):35-40.
\end{abstract}

BACKGROUND: Although infliximab is an effective therapy for inflammatory bowel disease (IBD), it is associated with dermatological events and infusion reactions. It is not known whether a relationship between these adverse events (AEs) and infliximab trough levels (ITLs) exists.

OBJECTIVES: To report the prevalence of infliximab-associated AEs in IBD patients receiving stable maintenance infliximab therapy, and to correlate ITLs with dermatological and infusion reactions to infliximab. METHODS: Adult IBD patients receiving stable maintenance infliximab therapy were recruited from the University of Alberta Infusion Clinic (Edmonton, Alberta). ITLs were measured in blood samples collected before infusion, and the patients' records were reviewed for dermatological and infusion reactions to infliximab.

RESULTS: One-quarter (18 of 71 [25.4\%]) of patients experienced dermatological or infusion reactions to infliximab: nine $(12.7 \%)$ dermatological events and nine (12.7\%) infusion reactions. The median ITL was similar among patients with and without these AEs $(7.2 \mu \mathrm{g} / \mathrm{mL}$ [interquartile range (IQR) $2.0 \mu \mathrm{g} / \mathrm{mL}$ to $13.3 \mu \mathrm{g} / \mathrm{mL}$ ] versus $6.6 \mu \mathrm{g} / \mathrm{mL}$ [IQR $3.2 \mu \mathrm{g} / \mathrm{mL}$ to $12.7 \mu \mathrm{g} / \mathrm{mL}$ ]; $\mathrm{P}=0.648)$. The median ITL of patients who experienced infusion reactions $(2.0 \mu \mathrm{g} / \mathrm{mL}$ [IQR $0.1 \mu \mathrm{g} / \mathrm{mL}$ to $5.7 \mu \mathrm{g} / \mathrm{mL}])$ was lower than that of patients who experienced no such AEs $(6.6 \mu \mathrm{g} / \mathrm{mL}$ [IQR $3.2 \mu \mathrm{g} / \mathrm{mL}$ to $12.7 \mu \mathrm{g} / \mathrm{mL}$ ]; P=0.008]) and lower than that of patients who experienced dermatological AEs $(13.3 \mu \mathrm{g} / \mathrm{mL}$ [IQR $8.8 \mu \mathrm{g} / \mathrm{mL}$ to $17.4 \mu \mathrm{g} / \mathrm{mL}$ ]; $\mathrm{P}<0.001$ ).

CONCLUSION: One-quarter of IBD outpatients receiving stable maintenance infliximab therapy experienced dermatological and infusion reactions. Low ITLs were correlated with infusion reactions, and normal or high ITLs with dermatological events.

Key Words: Adverse events; Infliximab; Infusion reaction; Trough level
Les nadirs d'infliximab sont corrélés avec les événements indésirables liés à ce médicament chez les patients ambulatoires atteints d'une maladie inflammatoire de l'intestin sous traitement d'entretien à l'infliximab

HISTORIQUE : L'infliximab est un traitement efficace des maladies inflammatoires de l'intestin (MII), mais il s'associe à des événements dermatologiques et à des réactions aux perfusions. On ne sait pas s'il y a un lien entre ces événements indésirables (ÉI) et les nadirs d'infliximab.

OBJECTIFS : Rendre compte de la prévalence d'ÉI liés à l'infliximab chez les patients atteints d'une MII qui reçoivent un traitement d'entretien stable à l'infliximab et les corréler avec les réactions aux perfusions d'infliximab.

MÉTHODOLOGIE : Les chercheurs ont recruté des adultes atteints d'une MII sous traitement d'entretien stable de l'infliximab à la clinique de perfusion de l'université de l'Alberta, à Edmonton. Ils ont mesuré les nadirs dans des échantillons de sang prélevés avant les perfusions et examiné le dossier des patients pour déterminer s'ils avaient eu des réactions dermatologiques à l'infliximab et des réactions aux perfusions de ce médicament. RÉSULTATS : Le quart des patients (18 sur 71 [25,4\%]) a présenté des réactions dermatologiques à l'infliximab ou aux perfusions de ce médicament, soit neuf événements dermatologiques $(12,7 \%)$ et neuf réactions aux perfusions $(12,7 \%)$. Le nadir médian était similaire chez les patients ayant subi ou non ces ÉI ( 7,2 $\mu \mathrm{g} / \mathrm{mL}$ [plage interquartile (PIQ) 2,0 $\mu \mathrm{g} / \mathrm{mL}$ à $13,3 \mu \mathrm{g} / \mathrm{mL}$ ] par rapport à $6,6 \mu \mathrm{g} / \mathrm{mL}$ [PIQ $3,2 \mu \mathrm{g} / \mathrm{mL}$ à $12,7 \mu \mathrm{g} / \mathrm{mL}$ ]; $\mathrm{P}=0,648)$. Le nadir médian des patients qui avaient des réactions aux perfusions $(2,0 \mu \mathrm{g} / \mathrm{mL}$ [PIQ $0,1 \mu \mathrm{g} / \mathrm{mL}$ à $5,7 \mu \mathrm{g} / \mathrm{mL}$ ]) était plus bas que celui des patients qui n'en avaient pas subi $(6,6 \mu \mathrm{g} / \mathrm{mL}$ [PIQ $3,2 \mu \mathrm{g} / \mathrm{mL}$ à $12,7 \mu \mathrm{g} / \mathrm{mL}] ; \mathrm{P}=0,008]$ ) et que celui des patients qui avaient subi des ÉI de nature dermatologique $(13,3 \mu \mathrm{g} / \mathrm{mL}$ [PIQ $8,8 \mu \mathrm{g} / \mathrm{mL}$ à $17,4 \mu \mathrm{g} / \mathrm{mL}$ ]; $\mathrm{P}<0,001$ ).

CONCLUSION : Le quart des patients ambulatoires atteints d'une MII sous traitement d'entretien stable à l'infliximab a subi des réactions dermatologiques et aux perfusions. Des nadirs bas étaient liés aux réactions aux perfusions, et des nadirs normaux ou élevés, aux réactions dermatologiques

Pathophysiological mechanisms that have been postulated to contribute to infliximab-induced adverse events differ depending on the adverse event; however, these reactions are believed to be mediated through the immune system. Pathogenesis may include the development of antibodies to infliximab (ATI), either immunoglobulin (Ig) E resulting in a hypersensitivity type reaction $(15,16)$ or $\mathrm{IgG}$ resulting in the formation of antibody/antigen complexes $(1,8,17-20)$, or induction of autoantibodies such as antinuclear, antidouble-stranded DNA and antihistone $(1,10,13,19)$. Dysregulation of the immune system and cytokine responses may also be involved (2,4-6,14,21-24). Given the importance of the pharmacodynamics of infliximab, the level of infliximab in the blood may be central to the generation of infliximabinduced side effects. However, to date, there have been no published imab, patients often must discontinue the medication $(9-14)$.

${ }^{1}$ Division of Gastroenterology, Department of Medicine; ${ }^{2}$ Division of Medical Biochemistry, Department of Laboratory Medicine and Pathology,

University of Alberta, Edmonton, Alberta

Correspondence: Dr Vivian Wai-Mei Huang, 2-14A Zeidler Building, University of Alberta, Edmonton, Alberta T6G 2 X8.

Telephone 780-492-6941, fax 780-492-8121, e-mail vwhuang@ualberta.ca

Received for publication August 18, 2014. Accepted November 24, 2014 
studies investigating the correlation between infliximab trough levels (ITLs) and infliximab-associated adverse events among IBD patients receiving stable maintenance infliximab therapy.

The aims of the present study were to report the prevalence of infliximab-associated dermatological and infusion reaction events among IBD outpatients receiving stable maintenance infliximab therapy, and to correlate ITLs with infliximab-associated adverse events.

\section{METHODS}

\section{Study design and setting}

The present cross-sectional study was conducted at the University of Alberta IBD Infliximab Infusion Clinic (Edmonton, Alberta) in 2013.

\section{Participants}

Consecutive IBD outpatients receiving infliximab maintenance therapy were systematically and prospectively identified at the infliximab infusion clinic and invited to participate in the present study. Patients were included in the study if they met the following criteria: a known endoscopic and histological and/or radiological diagnosis of Crohn disease (CD) or ulcerative colitis (UC); primary responders to the initial induction regimen of infliximab $5 \mathrm{mg} / \mathrm{kg}$ at weeks 0,2 and 6 (defined as a decrease in their Harvey-Bradshaw index after induction therapy by 3 points, or a decrease in their partial Mayo score to 0 or 1 ); receiving stable maintenance infliximab infusions (defined as infusions subsequent to the third induction dose or subsequent to the first infusion after any dose or interval change); and having complete records of infliximab infusions since initial induction. There were no specific exclusion criteria. All consented patients had blood for the determination of ITLs drawn immediately before their infliximab infusion, and underwent a detailed history and chart review to confirm infliximabassociated adverse events.

\section{Outcomes}

The primary outcome of the present study was the prevalence of infliximab-associated dermatological and infusion reaction adverse events among IBD outpatients receiving stable maintenance infliximab therapy. The secondary outcome was the correlation between ITLs and infliximab-associated adverse events.

\section{Data sources and definitions}

ITL: ITLs were determined on serum samples collected within $30 \mathrm{~min}$ before the beginning of the infusion. Serum was separated and frozen within $4 \mathrm{~h}$ of collection. An ELISA method (Immunodiagnostik, Germany) was used to quantify levels of free infliximab. Results are reported down to $0.4 \mu \mathrm{g} / \mathrm{mL}$, with an interassay precision of $8 \%$ at $1.8 \mu \mathrm{g} / \mathrm{mL}, 9 \%$ at $8.6 \mu \mathrm{g} / \mathrm{mL}$ and $20 \%$ at $12.9 \mu \mathrm{g} / \mathrm{mL}$.

Demographics and infliximab-associated adverse events: At the authors' centre, each infliximab infusion is characterized with the following: clinical disease activity scores (Harvey-Bradshaw index for $\mathrm{CD}$, partial Mayo for UC); health care provider documentation of infliximab-associated adverse events; and patient completion of a questionnaire of infliximab-associated adverse events.

Data were extracted from several sources by two of the authors (VH and ND) using a standardized case report form: electronic medical records; infusion questionnaires completed by the patient at the time of each infusion; nurse-generated infusion reports produced at the time of each infusion; and physician-generated clinic letters at the time of each infusion or subsequent clinic visits.

Infliximab-associated adverse events were classified as dermatological or infusion reactions. Dermatological adverse events were documented by a gastroenterologist and, when possible, confirmed by a dermatologist. Infusion reactions were documented by the infusion nurse and confirmed by a gastroenterologist. Acute infusion reactions were defined as any adverse reaction occurring during or within $24 \mathrm{~h}$ of an infusion, while delayed infusion reactions were defined as any adverse reaction occurring between $24 \mathrm{~h}$ and 14 days after an infusion. The data were reviewed by four of the authors $(\mathrm{VH}$, ND, KK and RF).
Demographic patient data included sex, age, type of disease, premedication with solumedrol or diphenhydramine, and concomitant immunosuppression (azathioprine, 6-mercaptopurine or methotrexate). Infliximab treatment characteristics were obtained from the above listed sources and included: infliximab dose in $\mathrm{mg} / \mathrm{kg}$; infliximab dosing interval in weeks; cumulative infliximab dose in mg; and number of infliximab infusions.

Time to infliximab-associated adverse event was calculated by determining the number of weeks from the first stable maintenance infliximab infusion until the first report of the infliximab-associated adverse event. Censoring occurred if the patient reported no infliximabassociated adverse events; time to censoring was calculated by determining the number of weeks from the first stable maintenance infliximab infusion until the ITL measurement.

\section{Study size}

A total of 100 consecutive IBD patients receiving stable maintenance infliximab therapy were recruited and consented to participate. However, the final evaluable sample size $(n=71)$ was determined by subsequent chart review, which excluded 29 patients due to incomplete infusion records.

\section{Statistical methods}

Continuous variables were presented as median (interquartile range [IQR]) due to the small sample size and nonparametric distributions. Nonparametric Mann-Whitney and Kruskall-Wallis tests were used to determine significant differences between median values. For categorical variables, proportions were calculated and comparison between subgroups was performed using Fisher's exact test; $\mathrm{P}<0.05$ was considered to be statistically significant.

\section{Ethics}

The present study was approved by the Health Research Ethics Board of the University of Alberta. Patients consented to provide a blood sample and allow review of their medical records.

\section{Patient characteristics}

\section{RESULTS}

Table 1 summarizes the demographic and infliximab treatment characteristics of the 71 evaluable patients. The number of men (39 of 71 [45.1\%]) and women (32 of 71 [54.9\%]) were similar, and there were more patients with CD (46 of 71 [64.8\%]) than patients with UC (25 of $71[35.2 \%])$. The median duration of time on stable maintenance infliximab therapy was 71.9 weeks (IQR 30.0 to 126.7 weeks), with a median time since last infusion of 7.0 weeks (IQR 4.1 to 8.0 weeks).

\section{Infliximab-associated adverse events}

More than one-quarter (18 of 71 [25.4\%]) of study participants experienced either a confirmed infliximab-associated dermatological event (nine of $71[12.7 \%]$ ) or an infusion reaction (nine of 71 [12.7\%]) while receiving maintenance infliximab therapy (Figure 1). Of the nine patients who experienced dermatological events, two $(22.0 \%)$ had psoriasis and seven $(77.8 \%)$ had persistent nonpsoriatic skin eruptions that had developed while on infliximab and were attributed to infliximab. Of the nine patients with infusion reactions, five $(55.6 \%)$ experienced acute infusion reactions and four (44.4\%) experienced delayed infusion reactions.

Comparing patients who experienced adverse events with those who did not, the median age was similar (Table 2). There were more women (12 of 18 [66.7\%]) than men (six of 18 [33.3\%]) in the group with adverse events $(\mathrm{P}=0.046)$. The proportions of $\mathrm{CD}$ and $\mathrm{UC}$ were similar between groups, with $62.3 \%$ (33 of 53) of patients without adverse events and $72.2 \%$ (13 of 18) of patients with adverse events having a diagnosis of $\mathrm{CD}$, and $37.7 \%$ (20 of 53) of patients without adverse events and $27.8 \%$ (five of 18) of patients with adverse events having a diagnosis of UC $(\mathrm{P}=0.445)$.

There were slightly more patients on concomitant therapy among those without adverse events (40 of 53 [75.5\%]) than among those 
TABLE 1

Demographics of inflammatory bowel disease outpatients receiving stable maintenance infliximab therapy at the Infliximab Infusion Clinic, University of Alberta, Edmonton, Alberta $(n=71)$

\begin{tabular}{ll}
\hline Characteristic & \\
\hline Age, years, median (IQR) & $38.0(26.0-47.0)$ \\
Sex & $39(54.9)$ \\
Female & $32(45.1)$ \\
Male & \\
Disease & $46(64.8)$ \\
Crohn disease & $25(35.2)$ \\
Ulcerative colitis & \\
Premedication & $28(39.4)$ \\
No & $43(60.6)$ \\
Yes & \\
Concomitant medication & $21(29.6)$ \\
No & $50(70.4)$ \\
Yes & \\
Infliximab history & $71.9(30.0-126.7)$ \\
Duration on stable dose, weeks, median (IQR) & \\
Dosing interval & $29(40.8)$ \\
$\quad<6$ weeks & $42(59.2)$ \\
$\quad 6$ weeks & $7.0(4.1-8.0)$ \\
Dosing interval, weeks, median (IQR) & $5.3(4.8-5.7)$ \\
Dose per infusion, mg/kg, median (IQR) & \\
\hline
\end{tabular}

Data presented as $n(\%)$ unless otherwise indicated. IQR Interquartile range

with adverse events (10 of 18 [55.6\%]) (P=0.110). There were slightly more patients receiving premedication among those who experienced adverse events (12 of 18 [66.7\%]) than among those without adverse events (31 of $53[58.5 \%])(\mathrm{P}=0.540)$.

ITLs and infliximab-associated adverse events

The median infliximab dose at the time of trough collection was $5.3 \mu \mathrm{g} / \mathrm{mL}$ (IQR 4.8 to $5.7 \mu \mathrm{g} / \mathrm{mL}$ ), with a median time since last infusion of 7.0 weeks (IQR 4.1 to 8.0 weeks). The median time to infliximabassociated adverse event was 38.2 weeks (IQR 18.0 to 94.7 weeks) and the median time to censorship was 73.1 weeks (IQR 34.0 to 143.1 weeks). As shown in Table 2, the proportion of patients who experienced dermatological or infusion reactions was similar among those receiving infliximab $<6$ weeks interval $(31.0 \%)$ and those receiving infliximab at $\geq 6$ weeks interval $(21.4 \%)(\mathrm{P}=0.360)$.

As shown in Figure 2A, patients who experienced any infliximabassociated adverse event during stable maintenance infliximab therapy had a median ITL of $7.2 \mu \mathrm{g} / \mathrm{mL}$ (IQR 2.0 to $13.3 \mu \mathrm{g} / \mathrm{mL}$ ), which was similar to the median ITL of patients who experienced no adverse events of $6.6 \mu \mathrm{g} / \mathrm{mL}$ (IQR 3.2 to $12.7 \mu \mathrm{g} / \mathrm{mL})(\mathrm{P}=0.648)$.

Dermatological adverse events: As shown in Figure 2B, patients who experienced infliximab-associated dermatological adverse events had a median ITL of $13.3 \mu \mathrm{g} / \mathrm{mL}$ (IQR 8.8 to $17.4 \mu \mathrm{g} / \mathrm{mL}$ ) while the patients who experienced no adverse events had a median ITL of $6.6 \mu \mathrm{g} / \mathrm{mL}$ (IQR 3.2 to $12.7 \mu \mathrm{g} / \mathrm{mL})(\mathrm{P}=0.058)$. The ITL of the two infliximabinduced psoriasis cases were $9.9 \mu \mathrm{g} / \mathrm{mL}$ and $13.3 \mu \mathrm{g} / \mathrm{mL}$.

Infusion reaction adverse events: In contrast, Figure $2 \mathrm{C}$ shows that patients who experienced infliximab-associated infusion reactions had a significantly lower median ITL of $2.0 \mu \mathrm{g} / \mathrm{mL}$ (IQR 0.1 to $5.7 \mu \mathrm{g} / \mathrm{mL}$ ) compared with the median ITL in those who experienced no adverse events of $6.6 \mu \mathrm{g} / \mathrm{mL}$ (IQR 3.2 to $12.7 \mu \mathrm{g} / \mathrm{mL}$ ) (P=0.008). Separating the infusion reactions into acute and delayed, the median ITL of those who experienced acute infusion reactions was lower $(0.60 \mu \mathrm{g} / \mathrm{mL}$ [IQR 0.20 to $3.1 \mu \mathrm{g} / \mathrm{mL}])$ compared with those who experienced delayed infusion reactions $(3.5 \mu \mathrm{g} / \mathrm{mL}$ [IQR 1.0 to $6.9 \mu \mathrm{g} / \mathrm{mL}])$, but the difference did not reach statistical significance $(\mathrm{P}=0.611)$. However, the

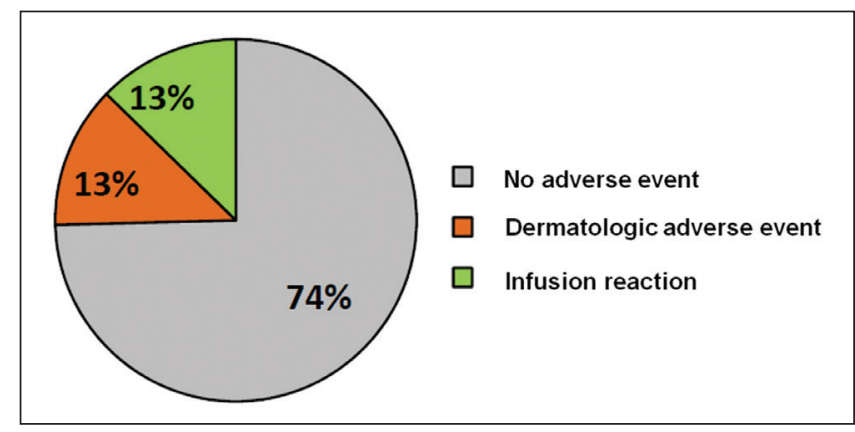

Figure 1) More than one-quarter of inflammatory bowel disease patients receiving stable maintenance infliximab therapy developed infliximab-associated adverse events

\section{TABLE 2}

Demographics of inflammatory bowel disease outpatients receiving stable maintenance infliximab therapy according to development of dermatological or infusion reaction to infliximab at the Infliximab Infusion Clinic, University of Alberta, Edmonton, Alberta $(n=71)$

\begin{tabular}{|c|c|c|c|}
\hline \multirow[b]{2}{*}{ Characteristic } & \multicolumn{2}{|c|}{ Adverse event* } & \multirow[b]{2}{*}{$\mathbf{P}$} \\
\hline & No & Yes & \\
\hline Total number & $53(74.6)$ & $18(25.4)$ & - \\
\hline $\begin{array}{l}\text { Age, years, } \\
\text { median (IQR) }\end{array}$ & $36.0(24.0-47.0)$ & $37.0(29.0-42.0)$ & 0.832 \\
\hline \multicolumn{4}{|l|}{ Sex } \\
\hline Female & $27(50.9)$ & $12(66.7)$ & 0.247 \\
\hline Male & $26(49.1)$ & $6(33.3)$ & \\
\hline \multicolumn{4}{|l|}{ Disease } \\
\hline Crohn disease & $33(62.3)$ & $13(72.2)$ & 0.445 \\
\hline Ulcerative colitis & $20(37.7)$ & $5(27.8)$ & \\
\hline \multicolumn{4}{|l|}{ Premedication } \\
\hline No & $22(41.5)$ & $6(33.3)$ & 0.540 \\
\hline Yes & $31(58.5)$ & $12(66.7)$ & \\
\hline \multicolumn{4}{|l|}{ Concomitant medication } \\
\hline No & $13(24.5)$ & $8(44.4)$ & 0.110 \\
\hline Yes & $40(75.5)$ & $10(55.6)$ & \\
\hline \multicolumn{4}{|l|}{ Infliximab history } \\
\hline $\begin{array}{l}\text { Duration on stable } \\
\text { dose (weeks) }\end{array}$ & $73.1(34.0-143.1)$ & $38.2(18.0-94.7)$ & 0.455 \\
\hline \multicolumn{4}{|l|}{ Dosing interval } \\
\hline$<6$ weeks $(n=29)$ & $20(69.0)$ & $9(31.0)$ & 0.360 \\
\hline$>6$ weeks $(n=42)$ & $33(78.6)$ & $9(21.4)$ & \\
\hline $\begin{array}{l}\text { Dosing interval, } \\
\text { weeks, median (IQR) }\end{array}$ & $7.0(4.1-8.0)$ & $5.6(4.0-7.6)$ & 0.839 \\
\hline $\begin{array}{l}\text { Dose per infusion, } \\
\mathrm{mg} / \mathrm{kg} \text {, median (IQR) }\end{array}$ & $5.3(4.8-5.7)$ & $5.1(4.9-5.5)$ & 0.195 \\
\hline
\end{tabular}

Data presented as $n(\%)$ unless otherwise indicated. *Dermatological or infusion reaction to infliximab. IQR Interquartile range

ITL in those who experienced acute infusion reactions $(0.60 \mu \mathrm{g} / \mathrm{mL}$ [IQR 0.20 to $3.1 \mu \mathrm{g} / \mathrm{mL}]$ ) was significantly lower than the median ITL of those who experienced no adverse reactions $(6.6 \mu \mathrm{g} / \mathrm{mL}$ [IQR 3.2 to $12.7 \mu \mathrm{g} / \mathrm{mL}])(\mathrm{P}=0.0167)$. The median ITL in those who had delayed infusion reactions $(3.5 \mu \mathrm{g} / \mathrm{mL}$ [IQR 1.0 to $6.9 \mu \mathrm{g} / \mathrm{mL}$ ]) was slightly lower than the median ITL of those who had no adverse reactions $(6.6 \mu \mathrm{g} / \mathrm{mL}$ [IQR 3.2 to $12.7 \mu \mathrm{g} / \mathrm{mL}])$, but the difference did not reach statistical significance $(\mathrm{P}=0.163)$.

Finally, as shown in Figure 2D, patients who experienced any infusion reactions had a significantly lower ITL, with a median of $2.0 \mu \mathrm{g} / \mathrm{mL}$ (IQR 0.1 to $5.7 \mu \mathrm{g} / \mathrm{mL}$ ), compared with patients who experienced dermatological events, with a median of $13.3 \mu \mathrm{g} / \mathrm{mL}$ (IQR 8.8 to $17.4 \mu \mathrm{g} / \mathrm{mL})(\mathrm{P}<0.001)$. 


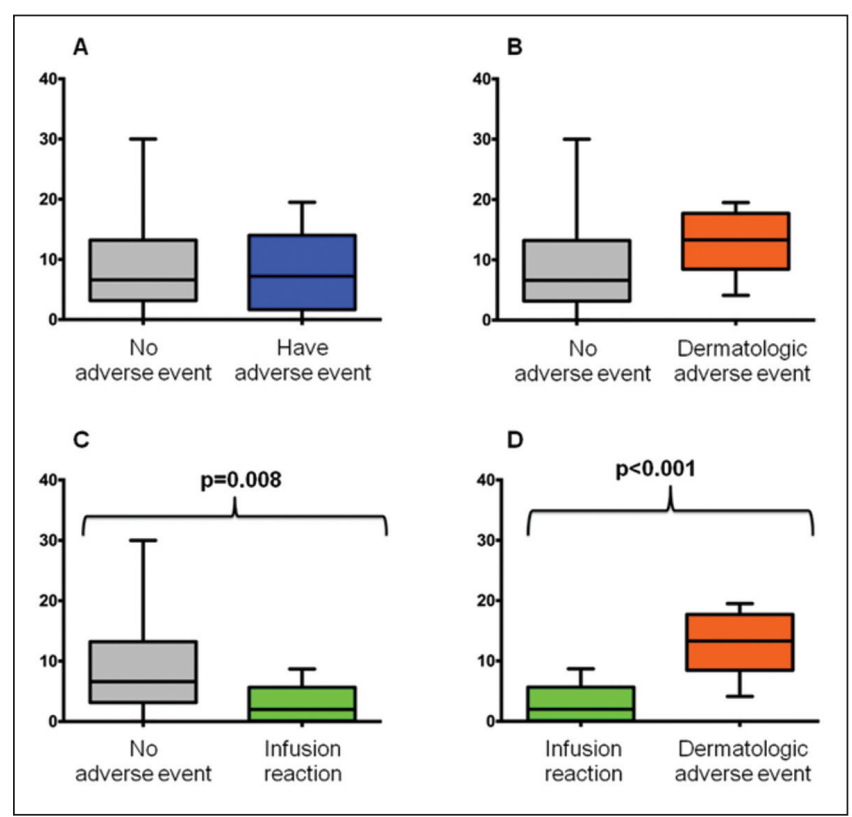

Figure 2) Infliximab trough level was correlated with type of infliximabassociated adverse event. No adverse event $(n=53)$, experience adverse event ( $n=18)$ (A); dermatological adverse event ( $n=9)$ (B); infusion reaction ( $n=9)$ (C); infusion reactions versus dermatological adverse events (D). Median, 25th percentile to 75 th percentile, minimum and maximum values for infliximab trough levels $(\mu \mathrm{g} / \mathrm{mL})$ are plotted

\section{DISCUSSION}

Infliximab is one of the cornerstone therapies for refractory CD and UC. In the present study, we demonstrated that more than one-quarter of IBD outpatients receiving stable maintenance infliximab therapy experience infliximab-associated dermatological or infusion reaction adverse events. In addition, we have shown a correlation between ITLs and the type of infliximab-associated adverse event: patients with dermatological adverse events had significantly higher ITLs, while patients with infusion reactions had significantly lower ITLs compared with patients who did not experience adverse events.

\section{Dermatological adverse events}

Paradoxical skin eruptions of eczema and psoriasis are common in patients receiving anti-TNF therapy, with up to $39 \%$ of reported cases of anti-TNF-induced psoriasis occurring in IBD patients $(5,25-27)$. Among studies specifically investigating IBD patients treated with anti-TNF therapies, the main focus has been on the induction or exacerbation of psoriasiform lesions, with reported incidence rates between $5 \%$ and $22 \%(1,4)$. The literature varies due to different inclusion criteria and definition of the skin lesions of interest.

In our study, we included both inflammatory skin lesions and any de novo skin eruptions that occurred during stable maintenance infliximab therapy, and estimated a prevalence of $12.7 \%$ for dermatological adverse events and $2.8 \%$ for anti-TNF-induced psoriasis. In a retrospective study conducted by Groupe d'Etude Thérapeutique des Affections Inflammatoires du tube Digestif (GETAID) centres in France, Rahier et al (12) estimated an incidence of 5\% for inflammatory skin lesions, with $2 \%$ for psoriasiform lesions and 3\% for eczematiform lesions. In a systematic analysis conducted in Madrid (Spain), Guerra et al (28) diagnosed 21 of 1294 IBD patients with anti-TNF- $\alpha$-induced psoriasis, $14(67 \%)$ of whom were being treated with infliximab; they reported a cumulative incidence of $1.62 \%$ (95\% CI $1.06 \%$ to $2.47 \%$ ). Of the 21 patients, 15 were female and 17 had CD. Eighteen patients developed new-onset psoriasis and, in virtually every case, the onset of psoriasis occurred during maintenance anti-TNF therapy. A systematic literature review of 69 published cases of IBD patients with infliximabinduced psoriasis, performed by Denadai et al (23), and a case series of
30 IBD patients with anti-TNF-related psoriasiform lesions conducted by Cullen et al (29) yielded similar findings with female sex and CD predominance. Similar to these studies, our study also showed a female sex and CD predominance among patients who experienced dermatological adverse events. These inflammatory skin lesions can be treated topically; however, up to $43 \%$ of patients require withdrawal of antiTNF therapies due to uncontrolled skin lesions $(12,24,29)$.

Although the underlying mechanism of infliximab-induced psoriasis is unknown, there is general consensus in the literature regarding a possible role for alterations in cytokine levels such as interferon (IFN)- $\alpha(1,2,24)$. It is proposed that anti-TNF- $\alpha$ agents, such as infliximab, decrease TNF- $\alpha$ inhibition of IFN- $\alpha$ production (23). Tillack et al (24) histologically examined psoriasiform skin lesions in anti-TNF treated IBD patients, and characterized them as having infiltrates with INF- $\alpha$-expressing cells. Consequently, the abnormally high levels of IFN $-\alpha$ resulting from decreased TNF- $\alpha$ inhibition can initiate psoriatic lesions. Although we did not measure cytokine levels in our study, the ITLs of patients who expereinced dermatological adverse events were higher than the ITLs of patients who did not.

Regarding dermatological adverse events, a limitation of the present study was the inclusion of skin eruptions documented by patient self-completed questionnaires; however, these data were only included if reported at least twice by patients, and confirmed by the gastroenterologist and, when possible, by a dermatologist, to have developed during infliximab therapy and attributed to infliximab therapy.

Based on our study findings and the pathophysiological mechanisms proposed in the literature, a management strategy for patients presenting with difficult-to-control infliximab-associated dermatological adverse events is to first measure ITLs. If the patient is clinically in remission and, if the ITLs are high, the infliximab dose should be lowered accordingly. If this dose adjustment and conservative measures are ineffective, then switching to another therapy may be required.

\section{Infusion reactions}

Infusion reactions to infliximab have been reported to occur in 5\% to $10 \%$ of all infusions among IBD patients $(30,31)$. When Steenholdt et al (32) examined 25 (8\%) of 315 IBD patients who experienced acute severe infusion reaction to infliximab, they found that IgG ATI levels were highly positive in 19 of 20 patients (95\%) after the reactions, but that IgE ATI was negative in all patients with reactions (32). The importance of ATI is emphasized in the systematic review and meta-analysis by O'Meara et al (33), which estimated risk ratios for any acute infusion reaction (RR 2.4 [95\% CI 1.5 to 3.8]; $\mathrm{P}<0.001)$ and severe infusion reactions (RR 5.8 [95\% CI 1.7 to 19]; $\mathrm{P}=0.004)$ that are higher in ATI-positive compared with ATInegative patients.

Delayed infusion reactions are believed to be type III immune complex-mediated reactions with formation of antigen-antibody complexes that deposit in the tissues (8). Interestingly, ATI may not be as important in the mechanism of action for delayed infusion reactions because O'Meara et al (33) showed that the RR of delayed hypersensitivity reactions is not significantly different between ATI-positive and ATI-negative patients (RR 2.8 [95\% CI 0.2 to 33]; P=0.4) (33).

In our study, patients who experienced delayed infusion reactions had slightly higher ITLs than patients who experienced acute infusion reactions, and slightly lower ITLs than patients who had no adverse events. Interestingly, patients who experienced acute infusion reactions had statistically significantly lower ITLs than patients who had no adverse events.

Regarding infusion reactions, a limitation of our study was the lack of antinuclear, anti-double-stranded DNA, antihistone, IgE levels, and of ATI levels in patients who developed infusion reactions. These measurements may have been beneficial to identify patients with drug-induced lupus, and also to confirm whether reactions occurred due to IgE-mediated versus ATI mechanisms. 
A limitation of the present study was the small number of dermatological and infusion reactions to infliximab. However, the prevalence of these adverse events is similar to that reported in previous studies, as mentioned above.

Another limitation was that at the time of the present study, we only had access to ELISA-based ITLs, but not to ATI levels. However, given the finding that the patients who experienced infusion reactions had lower ITLs, it would be important to determine whether they have ATIs. Both the ITL and the ATI level would be important to know in patients who develop adverse events such as infusion reactions to infliximab. Therefore, for future research studies, and also for clinical practice, it would be important to measure ATIs in patients who experience infusion reactions or who have low ITLs.

A strength of the present study was that it prospectively analyzed ITLs in all patients receiving stable maintenance infliximab therapy who consented to participate during the study period, regardless of whether they experienced dermatological or infusion reactions. This is in comparison with study designs that analyze ITLs in patients who have levels drawn for specific reasons (eg, loss of response or adverse events) because the latter study design would introduce selection bias into the analysis.

Based on the results of the present study, we propose a strategy to manage infusion reactions by measuring ITLs in patients who develop infusion reactions; if the ITL is low, ATIs should be measured with consideration to switch drugs if the patient has a high level of ATI.

\section{CONCLUSION}

Our study has shown that ITLs are correlated with infliximabassociated adverse events. Measurement of the ITL in patients who develop dermatological and infusion reactions to infliximab, with subsequent adjustment of infliximab dose may be a strategy to manage these infliximab-associated adverse events.

ACKNOWLEDGEMENTS: $\mathrm{VH}$ was supported by the Alberta Innovates Health Solutions (AIHS) Clinician Researcher Fellowship Award. DF was supported by the Cecile Mactaggart Summer Student Research Fund. This study was supported by the Alberta IBD Consortium and by the Centre of Excellence for Gastrointestinal Inflammation and Immunity Research (CEGIIR). RNF is acting as the article guarantor and contributed to study design, data analysis and manuscript editing. $\mathrm{VH}$ contributed to study design, data collection, data analysis and manuscript drafting and editing. ND contributed to study design, data collection and manuscript editing. DF, CP and CS contributed to data collection and manuscript editing. KIK, LAD and BPH contributed to data analysis and manuscript editing. All authors have approved the final version of the manuscript.

DISCLOSURES: RNF, KIK and LAD have served as speakers and consultants for AbbVie Canada Inc and Janssen Canada Inc. The remaining authors have no financial disclosures or conflicts of interest to declare. This work was presented at Digestive Diseases Week 2014 (May 3, 2014, AGA Forum - Adverse Events Related to IBD Therapy)

FUNDING SUPPORT: Alberta Innovates Health Solutions Clinician Researcher Fellowship. Centre of Excellence for Gastrointestinal Inflammation and Immunity Research, Alberta IBD Consortium.

\section{REFERENCES}

1. Fiorino G, Danese S, Pariente B, Allez M. Paradoxical immunemediated inflamamtion in inflammatory bowel disease patients receiving anti-TNF-a agents. Autoimmun Rev 2014;13:15-9.

2. Niess JH, Danese S. Anti-TNF and skin inflammation in IBD: A new paradox in gastroenterology? Gut 2014;63:533-5.

3. Moran GW, Lim AW, Bailey JL et al. Dermatological complications of immunosuppressive and anti-TNF therapy in inflammatory bowel disease. Aliment Pharmacol Ther 2013;38:1002-24.

4. Mocci G, Marzo M, Papa A, Armuzzi A, Guidi L. Dermatological adverse reactions during anti-TNF treatments: Focus on inflammatory bowel disease. J Crohns Colitis 2013:1-11.
5. Collamer AN, Guerrero KT, Henning JS, Battafarano DF Psoriatic skin lesions induced by tumor necrosis factor antagonist therapy: A literature review and potential mechanisms of action. Arthritis Rheum 2008;59:996-1001.

6. Collamer AN, Battafarano DF. Psoriatic skin lesions induced by tumor necrosis factor antagonist therapy: Clinical features and possible immunopathogenesis. Semin Arthritis Rheum 2010:40:233-40.

7. Hernández MV, Sanmartí R, Cañete JD, et al. Cutaneous adverse events during treatment of chronic inflammatory rheumatic conditions with tumour necrosis factor antagonists. Study based on the Spanish Registry of Adverse Events of Biological Therapies in Rheumatic Diseases. Arthritis Care Res 2013;65:2024-31.

8. Mayer L, Young Y. Infusion reactions and their management. Gastroenterol Clin North Am 2006;35:857-66.

9. Moss AC, Fernandez-Becker N, Jo Kim K, Cury D, Cheifetz AS. The impact of infliximab infusion reactions on long-term outcomes in patients with Crohn's disease. Aliment Pharmacol Ther 2008;28:221-7.

10. Yanai H, Shuster D, Calabrese E, Mlynarsky L, Tumuluri S, Cohen RD. The incidence and predictors of lupus-like reaction in patients with IBD treated with anti-TNF therapies. Inflamm Bowel Dis 2013:19:2778-86.

11. Hawryluk EB, Linskey KR, Duncan LM, Nazarian RM. Broad range of adverse cutaneous eruptions in patients on TNF-alpha antagonists. J Cutan Pathol 2012;39:481-92.

12. Rahier JF, Buche S, Biroulet LP, et al. Severe skin lesions cause patients with inflammatory bowel disease to discontinue anti-tumor necrosis factor therapy. Clin Gastroenterol Hepatol 2010;8:1048-55.

13. Verma HD, Scherl EJ, Jacob VE, Bosworth BP. Anti-nuclear antibody positivity and the use of certolizumab in inflammatory bowel disease patients who have had arthralgias or lupus-like reactions from infliximab or adalimumab. J Dig Dis 2011;12:379-83.

14. Denadai R, Teixeira FV, Saad-Hossne R. The onset of psoriasis during the treatment of inflammatory bowel diseases with infliximab: Should biological therapy be suspended? Arq Gastroenterol 2012;49:172-6.

15. Brennan PJ, Rodriguez Bouza T, Hsu FI, Sloane DE, Castells MC. Hypersensitivity reactions to mAbs: 105 desensitizations in 23 patients, from evaluation to treatment. J Allergy Clin Immunol 2009; 124:1259-66.

16. Hong DI, Bankova L, Cahill KN, Kyin T, Castells MC. Allergy to monoclonal antibodies: Cutting-edge desensitization methods for cutting-edge therapies. Expert Rev Clin Immunol 2012;8:43-54.

17. Casteele NV, Gils A, Singh S, et al. Antibody response to infliximab and its impact on pharmacokinetics can be transient. Am J Gastroenterol 2013;108:962-71.

18. Matucci A, Pratesi S, Petroni G, et al. Allergological in vitro and in vivo evaluation of patients with hypersensitivity reactions to infliximab. Clin Exp Allergy 2013;43:659-64.

19. Vultaggio A, Maggi E, Matucci A. Immediate adverse reactions to biologicals: From pathogenic mechanisms to prophylactic management. Curr Opin Allergy Clin Immunol 2011;11:262-8.

20. Vultaggio A, Matucci A, Nencini F, Pratesi S, Maggi E. Skin testing and infliximab-specific antibodies detection as a combined strategy for preventing infusion reaction. Intern Emerg Med 2011;7:77-9.

21. Roux $\mathrm{CH}$, Brocq O, Leccia N, et al. New-onset psoriatic palmoplantaris pustulosis following infliximab therapy: A class effect? J Rheumatol 2007;34:434-7.

22. de Gannes GC, Ghoreishi M, Pope J, et al. Psoriasis and pustular dermatitis triggered by TNF-\{alpha\} inhibitors in patients with rheumatologic conditions. Arch Dermatol 2007;143:223-31.

23. Denadai R, Teixeira FV, Steinwurz F, Romiti R, Saad-Hossne R. Induction or exacerbation of psoriatic lesions during anti-TNF- $\alpha$ therapy for inflammatory bowel disease: A systematic literature review based on 222 cases. J Crohns Colitis 2013;7:517-24.

24. Tillack C, Ehmann LM, Friedrich M, et al. Anti-TNF antibodyinduced psoriasiform skin lesions in patients with inflammatory bowel disease are characterised by interferon-expressing Th1 cells and IL-17A/IL-22-expressing Th17 cells and respond to anti-IL-12/ IL-23 antibody treatment. Gut 2014;63:567-77.

25. Kip KE, Swoger JM, Grandinetti LM, Barrie AM III, Greer JB, Regueiro MD. Tumor necrosis factor-\{alpha\} antagonist-associated psoriasis in inflammatory diseases. Inflamm Bowel Dis 2013;19:1164-72.

26. Shmidt E, Wetter DA, Ferguson SB, Pittelkow MR. Psoriasis and palmoplantar pustulosis associated with tumor necrosis factor. J Am Acad Dermatol 2012;67:e179-e185. 
27. Ko JM, Gottlieb AB, Kerbleski JF. Induction and exacerbation of psoriasis with TNF-blockade therapy: A review and analysis of 127 cases. J Dermatol Treat 2009;20:100-8.

28. Guerra I, Algaba A, Pérez-Calle JL, et al. Induction of psoriasis with anti-TNF agents in patients with inflammatory bowel disease: A report of 21 cases. J Crohns Colitis 2012;6:518-23.

29. Cullen G, Kroshinsky D, Cheifetz AS, Korzenik JR. Psoriasis associated with anti-tumour necrosis factor therapy in inflammatory bowel disease: A new series and a review of 120 cases from the literature. Aliment Pharmacol Ther 2011;34:1318-27.

30. Hanauer SB, Feagan BG, Lichtenstein GR et al. Maintenance infliximab for Crohn's disease: The ACCENT I randomised trial. Lancet 2002;359:1541-9.
31. Cheifetz A, Smedley M, Martin S, et al. The incidence and management of infusion reactions to infliximab: A large center experience. Am J Gastroenterol 2003;98:1315-24.

32. Steenholdt C, Svenson M, Bendtzen K, Thomsen OO, Brynskov J, Ainsworth MA. Severe infusion reactions to infliximab: Aetiology, immunogenicity and risk factors in patients with inflammatory bowel disease. Aliment Pharmacol Ther 2011;34:51-8.

33. O'Meara S, Nanda KS, Moss AC. Antibodies to infliximab and risk of infusion reactions in patients with inflammatory bowel disease. Inflamm Bowel Dis 2014;20:1-6. 


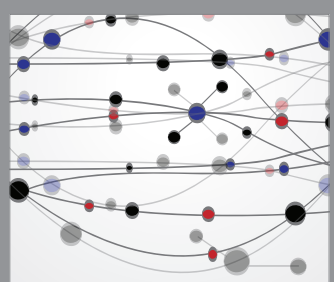

The Scientific World Journal
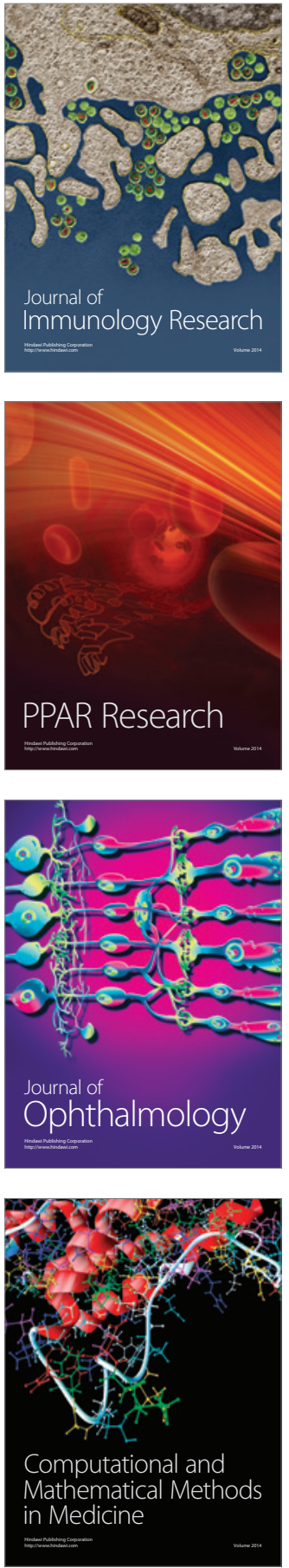

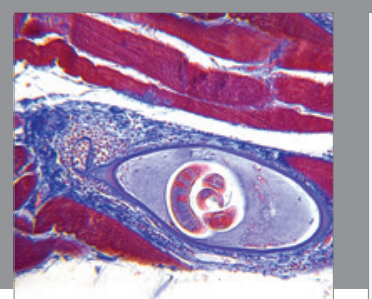

Gastroenterology Research and Practice

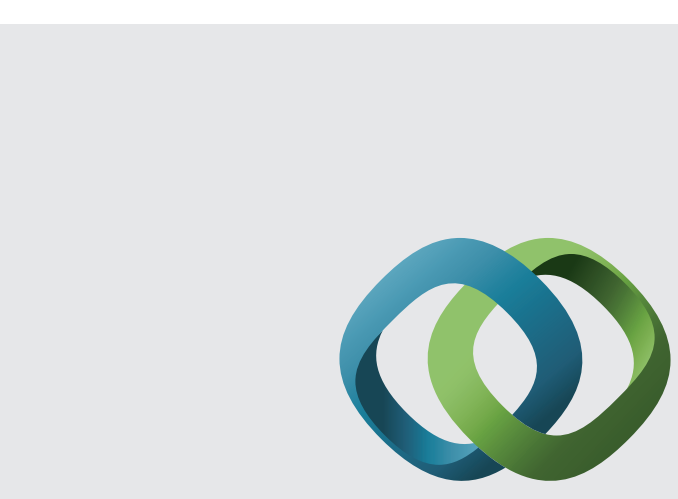

\section{Hindawi}

Submit your manuscripts at

http://www.hindawi.com
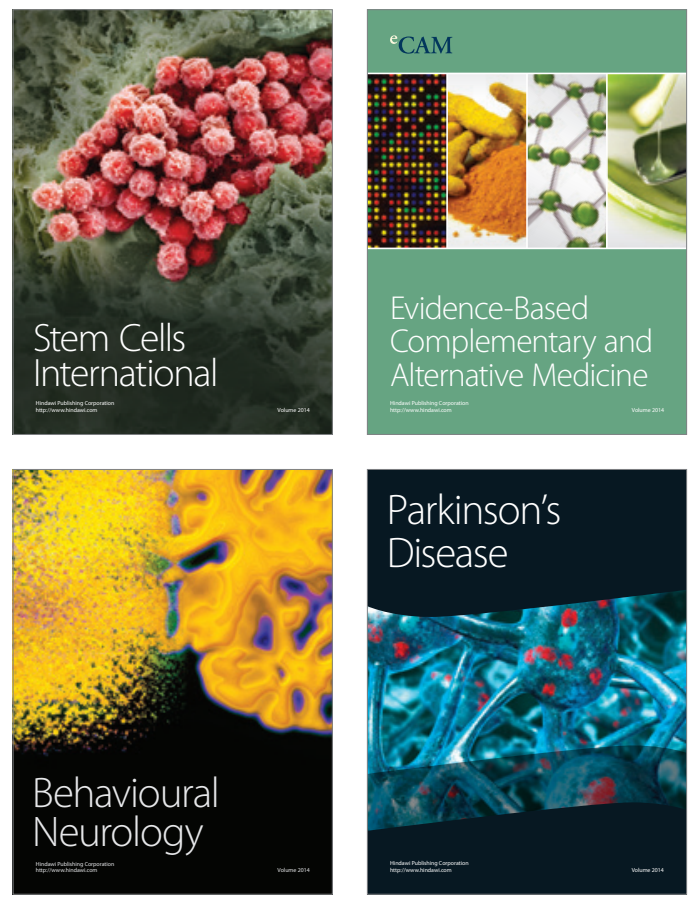
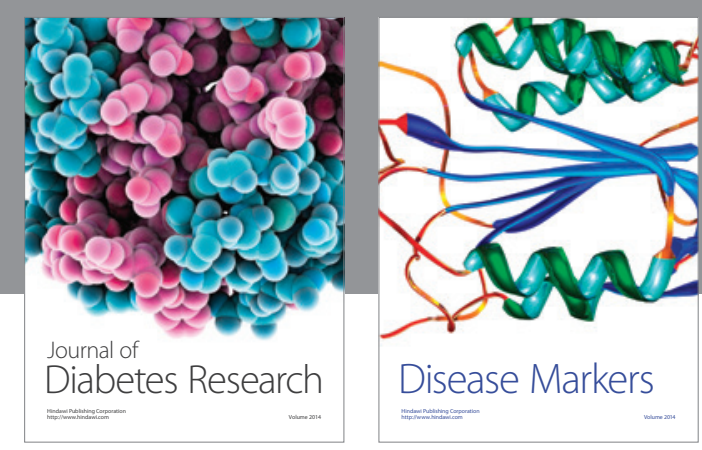

Disease Markers
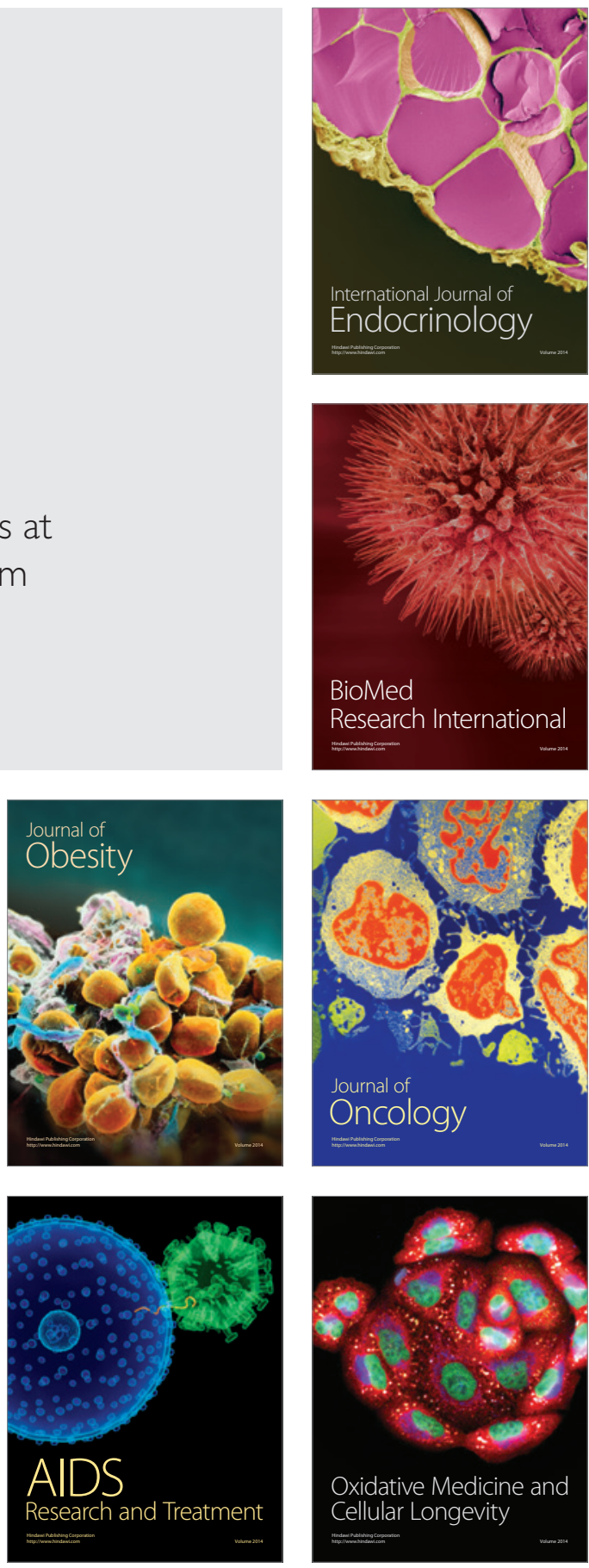